Article

\title{
Assessment of the Sustainability of a Real Estate Project Using Multi-Criteria Decision Making
}

\author{
Nomeda Dobrovolskiené ${ }^{1, * \mathbb{D}}$, Anastasija Pozniak $^{1}$ and Manuela Tvaronavičiené $^{2,3}$ \\ 1 Department of Financial Engineering, Faculty of Business Management, \\ Vilnius Gediminas Technical University, Saulètekio al. 11, LT-10223 Vilnius, Lithuania; \\ anastasija.pozniak@gmail.com \\ 2 Department of Business Technology and Entrepreneurship, Vilnius Gediminas Technical University, \\ Sauletekio 11, LT-10223 Vilnius, Lithuania; manuela.tvaronaviciene@jssidoi.org \\ 3 General Jonas Zemaitis Military Academy of Lithuania, Silo 5a, Šilo g., LT-10322 Vilnius, Lithuania \\ * Correspondence: nomeda.dobrovolskiene@gmail.com; Tel.: +370-686-322-23
}

Citation: Dobrovolskienè, N.;

Pozniak, A.; Tvaronavičienè, $\mathrm{M}$.

Assessment of the Sustainability of a

Real Estate Project Using

Multi-Criteria Decision Making.

Sustainability 2021, 13, 4352.

https://doi.org/10.3390/su13084352

Academic Editor:

Pierfrancesco De Paola

Received: 24 February 2021

Accepted: 9 April 2021

Published: 14 April 2021

Publisher's Note: MDPI stays neutral with regard to jurisdictional claims in published maps and institutional affiliations.

Copyright: (c) 2021 by the authors. Licensee MDPI, Basel, Switzerland. This article is an open access article distributed under the terms and conditions of the Creative Commons Attribution (CC BY) license (https:/ / creativecommons.org/licenses/by/ $4.0 /)$.

\begin{abstract}
Today, sustainability, sustainable development and clean environment come to the fore worldwide. Consequently, the concept of sustainability has been introduced in project management. Sustainability issues have gained particular attention in the real estate sector. However, despite the fact that this sector has a huge impact on the environment and society, real estate projects are most commonly chosen taking into account only their risk and return, and a very limited number of indices and methods are available to assess their sustainability. Moreover, all of the existing indices and models for assessing the sustainability of an investment project take into account only three dimensions of sustainability - environmental, social and economic. Therefore, the novelty of this work lies in constructing a real estate sustainability index (RESI) relying on an additional sustainability aspecti.e., a technological dimension. The developed sustainability index could be useful in evaluating and comparing real estate projects. It would also promote technological progress and investments in new technologies within projects as sustainability is also considered in a new, technological dimension. A research study was carried out between September 2020 and December 2020. Following an analysis of the literature and different sustainability-related standards relevant for the real estate industry, sustainability criteria were chosen and then grouped into four (environmental, social, economic and technological) categories. The selection and ranking of the most relevant sustainability criteria were performed through a survey. The index was compiled by applying multi-criteria decision making methods.
\end{abstract}

Keywords: sustainability; project management; real estate project; sustainability assessment; real estate sustainability index; multi-criteria decision making

\section{Introduction}

Sustainability concerns in delivering real estate projects have come to the fore in advanced economies [1,2]. The real estate sector creates a significant impact on the environment, social relationships and economic development. It is responsible for approximately $40 \%$ of energy consumption and $36 \%$ of $\mathrm{CO}_{2}$ emissions in the European Union. Moreover, this sector accounts for nearly 9\% of Europe's GDP [3]. Thus, building sustainability into real estate is inevitable in order to achieve a positive environmental impact. Projects are most commonly chosen taking into account only their risk and return, and there are very few indices and methods to assess the sustainability of a project. Consequently, there is a lack of knowledge and experience on how to use the methods and indices that are already developed and, more importantly, which method or index for measuring sustainability to choose. Moreover, all of the existing indices and models used to assess the sustainability of an investment project take into account only three dimensions of sustainability: environmental, social and economic [4,5]. However, there is an increasingly common trend observed in the recent 
scientific literature for the concept of sustainability to include more than just three main dimensions [6-11]. In this work, the authors seek to promote the integration of sustainability into real estate projects by incorporating a technological dimension within the concept of sustainability, which has been addressed in the literature. Consequently, a real estate sustainability index (RESI) is composed.

The aim of the present paper was to propose a tool to assess the sustainability of a real estate project, taking into account the technological dimension of sustainability.

With this aim in mind, a number of methods were employed, including a scientific literature review, comparison and synthesis. To construct a real estate sustainability index, multi-criteria decision making (MCDM) methods were employed, such as an expert survey, assessment of the compatibility and reliability of group opinions, subjective weighting, the reference value method and simple additive weighting (SAW).

This paper begins with a review of the scientific literature regarding the inclusion of the technological dimension in the sustainability concept. Section 3 reviews the scientific literature on sustainability in real estate investment projects. Section 4 presents a review of the literature related to sustainability measurement methods and gives an overview of MCDM methods. Section 5 introduces methodological procedures required for composing a real estate sustainability index. Section 6 describes the process of composing the real estate sustainability index. The last section summarizes the concluding remarks.

\section{Inclusion of the Technological Dimension in the Sustainability Concept}

Nowadays, sustainability is one of the biggest challenges for the society, as the growing human population and their activities bring environmental problems, including global climate change and urban pollution [12-17]. Sustainability is usually made up of three dimensions, namely environmental, social and economic, which are otherwise known as the "triple bottom line" [4,5]. Figure 1 represents each dimension and the relations between them.

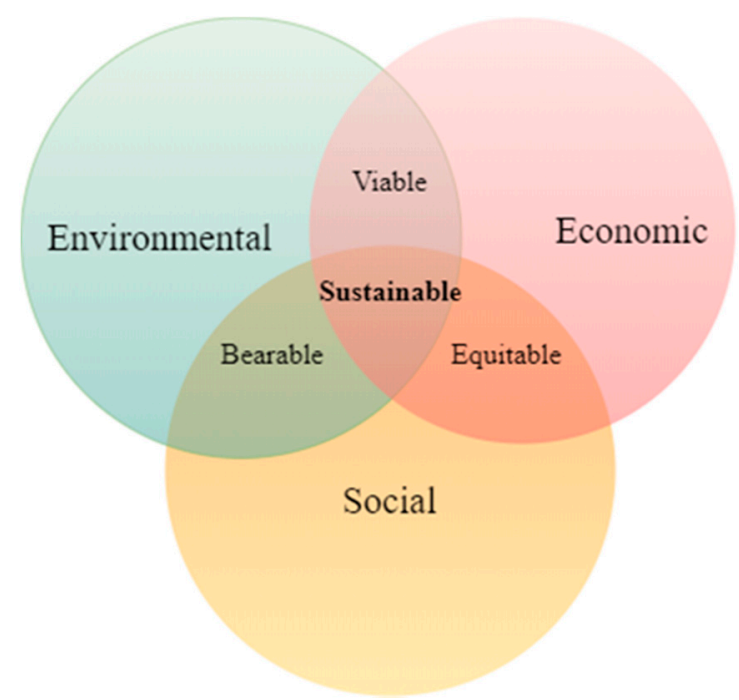

Figure 1. "Triple bottom line" concept of sustainability.

That is, sustainability not only foresees environmental protection and the prosperity of society but also includes economic development. By combining these three dimensions, the relation between each of them makes a society bearable, equitable and viable, which, in turn, creates a sustainable society. Thus, the concept of sustainability will be reached only by unifying those different aspects shown in Figure 1 as the "triple bottom line" construct, which primarily allocates and assigns equal importance to each dimension [4].

However, the literature review showed that some studies include and focus on only one dimension or combine two dimensions into one while defining sustainability, which, in turn, could make the notion limited. On the other hand, the sustainability concept in 
some studies also tends to include more than three main dimensions. Table 1 , below, shows how the sustainability concept is addressed in the literature.

Table 1. Concept of sustainability (1997-2021).

\begin{tabular}{ccc}
\hline Author(s), Year & Definition & Dimensions \\
\hline & In order to achieve a sustainable society, it needs to \\
meet three conditions: “ . . its rates of use of \\
renewable resources should not exceed their rates of \\
regeneration; its rates of use of non-renewable \\
resources should not exceed the rate at which \\
sustainable renewable substitutes are developed; \\
and its rates of pollution of emission should not \\
exceed the assimilative capacity of \\
the environment."
\end{tabular}

The concept of sustainability is far more complex than described in the literature and still requires integration of additional pillars (such as institutional, cultural and technological) into the concept, thus

Purvis, Mao, and Robinson, 2019 [7] requiring explicit description of how it is understood by various authors. Importantly, technological assistance should be integrated into the concept of sustainability.

Sustainability goes beyond basic statistics and has to cover multi-dimensional aspects. These dimensions include energy production, distribution, delivery and consumption and also consider technological Danish and Senjyu, 2020 [19] efficiencies; the pillars of sustainability are economic, social, institutional, technological and environmental.
Environmental, social, economic, institutional, cultural, technological
Environmental, social, economic, ecological, political, ethical, cultural, theological, technological 
As the above table demonstrates, the concept of sustainability is based, according to all of these authors, on the "triple bottom line" construct; however, in some scientific studies, the notion is altered or developed and expanded by including additional dimensions. One dimension that is becoming more commonplace in the literature is the technological aspect of sustainability [6-8,19]. The importance of embedding technology in the concept of sustainability is mainly explained by the fact that technology can contribute to the optimization of production resources and can adapt to changing conditions, such as amounts or characteristics of waste.

Due to increasing attention to the technological aspect in sustainability, in this paper, the sustainability concept is expanded and understood as conformity between the environmental, social, economic and technological aspects. The technological aspect is included while also defining sustainability with regard to the late Paris Agreement on climate change (signed in 2016) [23]. Thus, the inclusion of the technological dimension within the concept of sustainability adds novelty to the theoretical approach and valuation of projects' sustainability.

According to Bivainis [24], technology is the operation of a certain work object using working tools in order to turn it into a work product. Additionally, technology is a phenomenon which emerged in order to achieve targeted human impact on nature [25]. Work objects are diverse and evolving; thus, some of them become outdated, and new ones emerge as products of scientific and technical progress [24]. In addition, there is constant evolution of new technological devices in the construction and real estate sectors requiring an operative and rational use of products, buildings and civil engineering [26]. Therefore, according to Kildiene [26], this requires the development and implementation of innovative technologies, and the spreading of technological progress in a company's products and production process is necessary. Consequently, there is a need for training and education of technical and managerial personnel in crucial technologies that would allow for deriving environmental, economic and social benefits. Thus, the technological dimension also includes educational programs for technicians who will develop and work with these new technologies.

In general, the technological aspect is important, as it enables the development of new technologies that are able to reduce the impact on climate change and could make a positive contribution to clean energy generation [27-31]. More specifically, the technological aspect includes new technologies of hydrogen energy, nuclear energy and renewable energy in the definition of sustainability [32-34]. According to Nowotny et al. [27], photoelectrochemical and electrochemical technology is essential, as it could provide the needed large-scale storage for wind and solar energy. Besides, the usage of natural gas should be replaced by renewable energy sources through the adapted technologies. Moreover, sustainable fuel hydrogen requires new technologies for storage, transportation, distribution and safety.

Hence, the proposed modification of the original "triple bottom line" construct has an appearance as shown in Figure 2.

Thus, the "triple bottom line" construct is extended to encompass the technological dimension, and it seeks interrelation between the dimensions. In the light of the literature review [6-8,19-26], it can be concluded that with the inclusion of the technological aspect, companies are able to improve the quality of their project portfolio, which, in turn, allows them to satisfy the needs of stakeholders and, consequently, grants the opportunity to expand into new markets. Moreover, technological development can be an appropriate support for the improvement of the sustainability issue. Figure 3, below, shows the interrelation and importance of the technological aspect in the environmental, economic and social dimensions. 


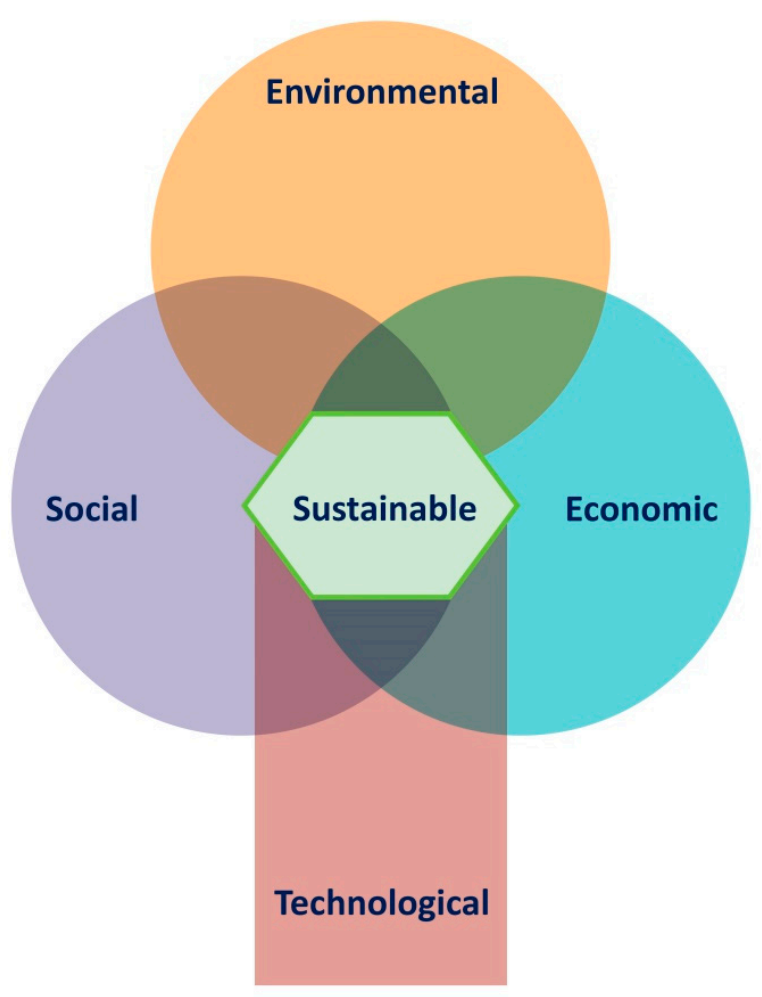

Figure 2. Modified "triple bottom line" construct.

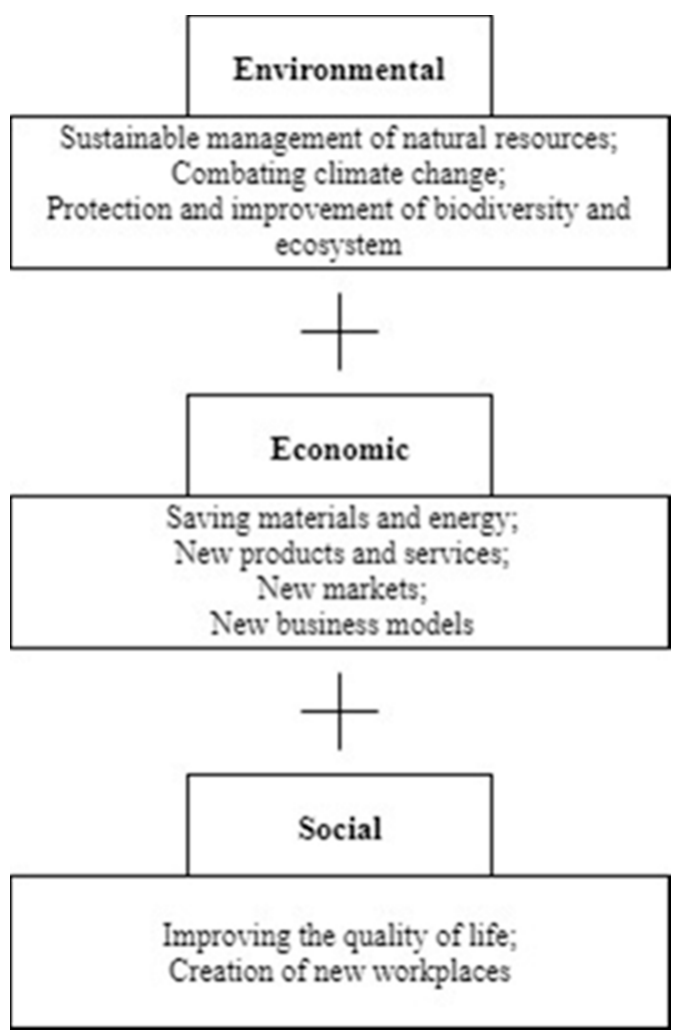

Figure 3. Technological features in sustainability dimensions.

Technological innovations are, therefore, necessary, as they also allow for improving each of the original "triple bottom line" sustainability dimensions. In fact, they could help achieve more efficient use of resources, improve cost effectiveness, provide a competitive 
advantage in the market, maintain and improve living standards and quality as well as reduce the usage of toxic materials [26].

Finally, the original "triple bottom line" concept (consisting of the environmental, social and economic dimensions) is complemented by an additional technological dimension further in this work, as the development and employment of new clean energy technologies are needed in order to transition to a sustainable future, and without the technological component, the understanding of sustainability cannot be considered complete. Besides, technology nowadays is viewed as a core factor of a company's competitive advantage, as it allows for pursuing and achieving better performance [35].

\section{Increasing Focus on Sustainability in Real Estate Investment Projects}

According to some authors $[13,14,36,37]$, the concept of sustainability is widely used in construction and real estate projects. This can be explained by the fact that real estate projects have a significant impact on the natural environment, society and the economy $[13,14]$. The real estate industry is a driver of economic growth, as it builds links between the real estate sector and other sectors, which, in turn, plays a significant role in the development of the economy [38].

More specifically, as reported by the European Commission [3], real estate projects are responsible for about $40 \%$ of energy consumption and $36 \%$ of $\mathrm{CO}_{2}$ emissions in the European Union. Furthermore, according to Durdyev et al. [38], the real estate sector also accounts for the production of $40 \%$ of raw materials, $25 \%$ of timber consumption, $40 \%$ of solid waste production and $16 \%$ of water consumption worldwide. It is also said that the real estate building sector is responsible for the largest use and consumption of primary energy compared to other major economic sectors, such as industry and transportation [39]. As stated in the European Commission's report [3], nearly 35\% of existing buildings in the European Union are over 50 years old and, thus, energy inefficient. Consequently, technological improvements in old buildings would significantly boost energy efficiency [39].

The sustainability concern should be considered and incorporated into real estate projects more widely, given the requirement laid down in the Energy Performance of Buildings Directive that all new buildings should be nearly zero-energy buildings from 31 December 2020. According to this directive, the amount of energy should come from renewable energy sources [40]. As stated by Eurostat [41], the Europe 2020 strategy is aimed at achieving three main objectives and priorities: smart growth, sustainable growth and inclusive growth. Thus, according to Dobrovolskiene [14], these priorities are closely related to the real estate sector, as it has a direct impact on reducing greenhouse gas (GHG) emissions by at least $20 \%$ compared to 1990 levels, increasing the share of renewable energy to $20 \%$ of overall energy consumption and increasing energy efficiency by $20 \%$.

The concept and understanding of sustainable building are evolving; once focused on the environmental aspect, mainly concerned with efficient energy use, technical efficiency and functional requirements, the concept now covers both social and economic aspects as well [42]. Thus, the real estate industry addresses basic social and physical needs, which include infrastructure, production of accommodation and consumer goods [38]. In addition, according to Kildiene [26], the main purpose of sustainable building is to guarantee that new constructions will save energy and resources and protect and ensure the health and the well-being of people. Lazauskas [43] suggests that the sustainability of a real estate project be implemented through society's participation in decision making and modern decision making theories, while justifying complex solutions for assessing the sustainability of a real estate project, which would ensure the satisfaction of the future needs of society.

It is also clear that sustainable buildings bring financial benefits, as investments in water and energy efficiency solutions result in operational savings [44]. Moreover, the higher standard of a building leads to long-term value proposition, lower vacancy rates and higher rent levels [42]. Furthermore, it facilitates the attraction of the right employees that prefer working in green and high-quality buildings. 
As the real estate industry generates nearly 9\% of Europe's GDP, investments in the sustainability of real estate and its construction processes are crucial and inevitable and should be recognized as a high priority in global strategies of climate change [3,39]. Therefore, this is a prevailing challenge, and the mission of present generations is to construct buildings that ensure a positive impact on climate and environment.

\section{Sustainability Measurement Tools for Real Estate Projects}

With particular emphasis being placed on the integration of sustainability into real estate project management, in order to use energy efficiently and protect the environment within projects implemented in this sector, sustainability-focused systems and assessment methods have been developed [14,45]. Among all certification systems and sustainable building evaluation methods, the most popular ones are the German Sustainable Building Council (DGNB), Leadership in Energy and Environment Design (LEED) and the Building Research Establishment Environmental Assessment Method (BREEAM) [46]. These methods define a set of criteria and a rating system and score them on the basis of the criteria importance factor [47]. According to the analysis made by Hamedani and Huber [47], the DGNB, LEED and BREEAM certification systems include groups of criteria such as climate and energy, resources, transport and movement, community, ecology and biodiversity, business and economy, smart location, green infrastructure, innovation and design process, ecological and economical quality, sociocultural and functional, technical and process qualities. That is, these evaluation systems are focused on energy saving, water efficiency, reducing $\mathrm{CO}_{2}$ emissions, improving the internal quality of life and management and appropriate use of resources $[13,26]$. Several studies were conducted to distinguish the differences between many of the well-known sustainability rating tools (e.g., BREEAM and LEED). Some of these studies highlighted the differences in the assessment criteria of these tools and their weighting schemes, which change from a regional context to another [45].

In addition to the most popular and well-known certification systems mentioned above, other sustainability assessment methods were found in the literature $[26,43,48-50]$. For instance, Kaklauskas et al. [48] developed, after having conducted a comprehensive examination of macro-, meso- and microenvironment variables, a passive house evaluation method, which is based on the Population and Health Management Information System (PHMIS). Morano et al. [49] proposed to use a cost-revenue analysis in the decision making process concerning the enhancement of a military complex located in the city of Rome. This assessment methodology is appropriate and characterizes the preliminary phases of the initiative, for which indications required concern only the extent of amounts involved. Bottero and Ferretti [50] proposed to use a comprehensive key environmental indicator framework and multi-criteria analysis to assess the sustainability of different strategies. The assessment model provides priority lists of the importance of the considered indicators and alternatives. Vučićević et al. [51] presented a method for the selection and calculation of sustainable development indicators. Kildienè [26] proposed a complex algorithm of a multilevel decision-making model, under which the sequence of indicator evaluation allows for combining quantitative and qualitative indicators. Lazauskas [43] presented a complex decision-making model, which is made of a set of indicators that address effective implementation difficulties of projects in the construction market. Siew et al. [52] presented methods that allow for evaluating sustainability by applying two important stages: selection (sustainability criteria are suggested and the project's sustainability is evaluated) and formation of an optimal portfolio (means and dispersions obtained from the selection stage are used to find an effective portfolio limit).

The analysis of the scientific literature shows that sustainability indicators are considered the main and most effective tools for assessing sustainability used in decision making [13,14,53-60]. A wide range of sustainability indicators have been constructed for various stakeholders and used in different situations across the world, employing different approaches $[13,37,40-57,60-71]$. However, only a few sustainability indices are found in the scientific literature, which are designed to measure the level of sustainability 
of construction and real estate projects $[13,14,37]$. For example, Dobrovolskienè and Tamošiūniene [13] developed an index to measure the level of sustainability of a business project in the construction industry. The index is comprised of 15 sustainability criteria, to which greater importance was attributed by construction practitioners. These include four economic, five social and six environmental criteria. Dobrovolskienè et al. [37] constructed a composite sustainability index for real estate projects, which consists of 21 sustainability criteria (five in economic equity, eleven in environmental preservation and five in the social justice category). The two abovementioned indices covered only three sustainability dimensions - environmental, social and economic. Therefore, inspired by the previous works $[13,37]$ and in view of the importance of integrating the technological dimension into the development of a tool to assess the sustainability of a project, this paper attempts to compensate for the lack of empirical studies in this field of research by developing a real estate sustainability index using MCDM methods.

MCDM methods are widely used in composing indices due to their ability to include multiple and, in some cases, conflicting criteria [14,55,62,72-80]. According to Si et al. [39], MCDM methods allow for transforming a complex problem of decision making into welldefined steps, which will lead to the selection of an optimal solution. As claimed by Korotkov and $\mathrm{Wu}$ [81], MCDM methods are very important when choosing a project from the portfolio of investment projects, which often have conflicting objectives, in order to meet the investor's requirements regarding a particular project. MCDM methods help to compare the alternatives to and importance of criteria using mathematical models and expressions. Thus, MCDM methods are applied further in this work to select the most sustainable project.

MCDM methods usually fall into two categories: multiple objective decision making (MODM) and multiple attribute decision making (MADM) $[13,14]$. In the case of MODM, decision alternatives are not given, and it is aimed at optimizing objectives while linking other objectives to a constraint set by applying programming, whereas MADM allows for evaluating and comparing a discrete number of alternative indicators [82,83].

Various multiple-criteria methods are currently used: geometric mean (GM), sum of ranks (SR), analytic hierarchy process (AHP), simple additive weighting (SAW), technique for order preference by similarity to an ideal solution (TOPSIS), Visekriterijumsko Kompromisino Rangiranje (VIKOR), complex proportional assessment (COPRAS), Elimination and Choice Expressing Reality (ELECTRE) and the Preference Ranking Organization Method for Enrichment Evaluation (PROMTHEE) [14,84]. That is, there are a lot of MCDM methods described in the recent literature, but there is no consensus as to which method is best suited for problem solving [14]. However, as the literature analysis showed, the most popular methods are SAW and TOPSIS [84].

Simple additive weighting (SAW) is the best-known and most widely used MCDM method $[14,85,86]$. It is a method of the MADM category, as it allows for assigning significance or weight to each attribute of a set of alternatives and then providing the process for selecting the best alternative [75]. As the name suggests, the SAW method performs a weighted summation. According to Ibrahim and Surya [87], the alternative that will be considered as the best of the alternatives and that will be recommended in the end is the one that has the highest weighted summation or score.

TOPSIS is another well-known MCDM method of the MADM category, which allows for finding the best solution or alternative while defining the shortest distance from the ideal solution and the farthest distance from the worst or negative ideal solution [88]. Thus, the core process of the TOPSIS method consists of finding the positive ideal solution and negative ideal solution, and consequently, the results and ranking are based on the relative closeness coefficient [89].

Even though these methods are commonly used, there are some constraints reported in the literature as to which one is the best. For example, Zimmer, Fröhling and Schultmann [90], having reviewed MCDM methods, concluded that the TOPSIS method is the dominant one. On the other hand, according to Roszkowska [91], the TOPSIS method is far 
from ideal: it does not provide for consistency and weight extraction in decision making. However, Roszkowska [91] also claims that this technique still has important advantages: it is simple, rational and contains clear logic, making it easy to check performance relative to each alternative. As regards the SAW method, its advantage is that it is easy to apply; that is, it is a linear function of a criterion multiplied by its significance weight [92]. On the other hand, this method allows for comparing only those variables and criteria that are maximizing; therefore, minimizing variables need to be transformed into maximizing ones [93].

In light of the above, MCDM methods are popular and easy-to-apply tools that allow for combining conflicting criteria and selecting an optimal solution. According to the literature review [78-87], the most appropriate means to assess the sustainability of a real estate project is by applying MCDM methods, which allow for including conflicting criteria.

\section{Methodological Procedures for Composing a Real Estate Sustainability Index}

Building on previous works [13,37], the present study was carried out in accordance with the following sequence of methodological procedures:

Identification of criteria: On the basis of a review of the related literature or an expert survey, a set of criteria is compiled and indicators reflecting those criteria are formulated. The criteria are then assigned to four categories (i.e., environmental, economic, social, and technological).

Development of a key criteria framework: A key criteria framework is constructed using the critical value as a basis, since, for assessment to be adequate, the framework has to include a complete set of relevant criteria affecting the research phenomenon $[55,94]$. Given that each criterion affects the research phenomenon differently, it is necessary to evaluate which criteria in particular should be included in the framework. This is a subjective process depending on the qualifications of experts (i.e., only those criteria that are judged relevant by experts are included in the framework). The framework may also contain a limited set of criteria, as an excessive number of criteria can make it difficult to measure the impact of each criterion on the final result. The key criteria may be selected in a number of different ways. With a limited set of criteria $\mathrm{m}(\mathrm{m}<20)$, the weights $w_{i}$ of criteria $K_{i}(i=1,2, \ldots, \mathrm{m})$ may be determined by using, for instance, Saaty's pairwise comparison method [95]. This method, however, has the inherent disadvantage of allowing decision makers to choose the cut-off values of weights, which results in an individual composition of a subset. On the other hand, where decision makers are highly qualified, the key criteria are essentially the same across all lists of individual experts and, thus, form a solid basis for a criteria framework.

Weighting of indicators: Relative significance is attributed to each criterion. Once responses to the expert survey are received, the significance of criteria should be defined. The main idea is that the most significant criterion should have the highest weight $w_{i}$. The sum of weights has to be equal to one [93]:

$$
\sum_{i=1}^{m} w_{i}=1
$$

In this case, significance determination and weight assignment are based on the evaluation of expert opinions. The opinions of experts are often divergent regarding a particular problem; therefore, there is a need to determine the degree of agreement between the expert opinions. Agreement between two experts can be measured by the correlation coefficient. Where the number of experts is greater than two, the level of agreement among the group experts is assessed by the coefficient of concordance [96]. Consequently, Kendall's coefficient of concordance $W$ is applied, which is calculated according to the following formula [97]:

$$
W=\frac{12 S}{m^{2}\left(n^{3}-n\right)}
$$


where:

- $W$ is Kendall's coefficient of concordance;

- $S$ is the sum of the deviation of ranks from the mean;

- $n$ is the number of objects (criteria) $(i=1,2, \ldots, n)$;

- $\quad m$ is the number of experts $(j=1,2, \ldots, m)$.

$W$ is interpreted as follows: if $W$ is equal to 0 , there is no agreement between expert opinions; 0.10 -agreement is weak; 0.30-agreement is moderate; 0.60-agreement is strong; $W$ of 1 indicates perfect agreement between the expert opinions $[13,37]$.

The next step is to verify the reliability of the expert opinions. This can be calculated using Pearson's correlation coefficient [34]:

$$
\chi^{2}=m(n-1) W
$$

which is distributed by the $\chi^{2}$ distribution with $v=n-1$ degree of freedom. At the selected level of significance $\alpha$ (in practice, the value of $\alpha$ is 0.05 or 0.01 ), the critical value $\chi_{k r}^{2}$ is obtained from the table of the $\chi^{2}$ distribution with $v=n-1$ degree of freedom. If the value of $\chi^{2}$ calculated in accordance with Formula (2) is greater than $\chi_{k r}^{2}$, expert assessments are in agreement.

Normalization of weights: This step involves transformation of indicators, which are usually expressed in distinct measurement units. As a result, the normalized values should be in the interval $(0 ; 1)$. Among the possible normalization methods [55], the distance to a reference method requires the calculation of a ratio between an indicator and an external target value (i.e., benchmark). The latter can be defined by industry-specific norms and standards, legal regulations or any other relevant source of information $[13,14,37,97]$. When this method is used, each indicator is primarily classified as maximized (meaning that the higher the value of an indicator is, the more positive impact it has on sustainability) or minimized (meaning that the lower the value of an indicator is, the less negative impact it has on sustainability). There are methods (e.g., SAW) able to deal only with maximized indicators; therefore, minimized indicators have to be transformed (i.e., normalized) into maximized ones according to Formula (4) [98]:

$$
\widetilde{r_{i j}}=\frac{\min _{j} r_{i j}}{r_{i j}}
$$

where $r_{i j}$ is the value of the $i$ th indicator for the $j$ th alternative, and $\min r_{i j}$ is the smallest value of the $i$ th indicator. After normalization of variables, the smallest value obtains the largest value equal to one. Similarly, the values of maximized indicators can be transformed so that the largest value of an indicator acquires the largest value equal to one:

$$
\widetilde{r_{i j}}=\frac{r_{i j}}{\max _{j} r_{i j}}
$$

where $\max r_{i j}$ is the largest value of the $i$ th indicator.

Aggregation of indicators: The most common procedure is the summation of the weighted normalized individual indicators (i.e., SAW) $[13,14,37]$. The sum $S_{j}$ of the weighted normalized values of all indicators is calculated for every jth object according to Formula (6) [13]:

$$
S_{j}=\sum_{i=1}^{m} \omega_{i} \widetilde{r_{i j}}
$$

where $\omega_{i}$ is the weight of the $i$ th indicator, and $\widetilde{r_{i j}}$ is the normalized value of the $i$ th indicator for the $j$ th object and $\sum_{i=1}^{m} \omega_{i}=1$.

Analysis and discussion of the results: finalization of the study. 


\section{Results and Discussions}

This section presents a real estate sustainability index, which was constructed following the methodological process described in the previous section. Based on the analysis of the literature $[13,34,55,97,99-109]$, a total of 35 criteria were selected, which were then divided into social (9 criteria), environmental (10 criteria), economic ( 8 criteria) and technological (8) groups.

An expert survey was carried out in two stages. During the first stage, a survey form was prepared with two sets of questions: general information about the expert and information about sustainability criteria for a real estate project. In the first set of questions, experts were asked three questions regarding their academic degree, work experience in examining project sustainability and country and city of residence. In the second set of questions, experts were asked to rate the significance of the criteria of each sustainability dimension separately (environmental, social, economic and technological).

The survey form was sent to 12 experts, taking into account their educational background and experience in carrying out and managing sustainable projects. Answers were received from nine experts, of which six have a PhD degree, with 5 to 19 years of experience in dealing with project sustainability; one expert with a Master's degree and 5 years of experience; one professor with 10 years of experience; and one engineer with 15 years of experience in working on and managing sustainable projects. Responsiveness to this survey was, therefore, considered to be high enough (75\%). It appears, according to the literature [15], that a smaller number of experts taking part in a survey produces results of equivalent accuracy as surveys involving a large number of experts; therefore, it was decided that nine experts were enough to conduct a survey and rely on their opinions in order to construct a real estate sustainability index. There were also a few meetings arranged with all of the experts in order to obtain the most reliable results by clarifying the criteria in person. The experts had to assign significance to each criterion within each dimension using a 5-point system, with 1 being least significant and 5 being the most significant.

After receipt of the responses, the mean value of each criterion was determined. The critical significance mean value was established at 3.5, as having too many criteria could impact the results by creating biases, which would lead to inappropriate evaluation of the final result $[13,14,37]$. Accordingly, the most important sustainability criteria with a mean value higher than or equal to 3.5 were selected. As a result, 18 significant criteria remained (5 environmental, 3 social, 5 economic and 5 technological).

In the second stage, a list comprising the 18 most significant criteria was sent to the same nine experts, asking them to assign significance to all these criteria, where the most significant criterion was given 18 points, and the least significant criterion was given 1 point. Responses were received from all those experts. Based on their responses, the total number of points was calculated for each criterion. The results are presented in Table 2 below.

Table 2. Significance points for sustainability criteria.

\begin{tabular}{cccc}
\hline Dimension & Criterion & Units of Measurement & Total Points \\
\hline Environmental & Emission of $\mathrm{CO}_{2}$ & $\mathrm{CO}_{2} \mathrm{t} /$ Net income & 152 \\
\hline Social & Health and well-being of workers & $\begin{array}{c}\text { Cost of safety equipment provided/Total cost } \\
\text { of materials }\end{array}$ & $\begin{array}{c}\text { Number of experienced employees able to } \\
\text { design, build and use the technology/Total } \\
\text { number of employees }\end{array}$ \\
\hline Technological & Employment of innovative & technologies & Costs of repairs after construction/Net income \\
\hline Technological & Overall project quality & Renewable energy/All energy & 112 \\
\hline Environmental & Use of renewable energy & Prevention costs/All costs & 110 \\
\hline Economic & Quality control & 103 & \\
\hline
\end{tabular}


Table 2. Cont

\begin{tabular}{|c|c|c|c|}
\hline Dimension & Criterion & Units of Measurement & Total Points \\
\hline Environmental & Waste management & Tons of waste managed/Tons of waste capacity & 98 \\
\hline Technological & $\begin{array}{l}\text { Technical risks throughout the } \\
\text { project life-cycle and feasibility }\end{array}$ & $\begin{array}{l}\text { Cost of technology repairs/Total cost } \\
\text { of technology }\end{array}$ & 96 \\
\hline Technological & $\begin{array}{l}\text { Degree of intellectual property } \\
\text { protection (patents, } \\
\text { trademarks, copyrights) }\end{array}$ & $\begin{array}{l}\text { Cost of intellectual property protection/Total } \\
\text { cost of technology }\end{array}$ & 92 \\
\hline Social & Improvement of the life quality & $\mathrm{m}^{2}$ of green zones created/Net income & 71 \\
\hline Economic & Time of construction & Number of months/Net income & 66 \\
\hline Environmental & $\begin{array}{l}\text { Post-construction energy } \\
\text { consumption }\end{array}$ & GJ/Net income & 65 \\
\hline Economic & Reduction of direct costs & Direct costs / All costs & 64 \\
\hline Economic & Reduction of non-direct costs & Non-direct costs / All costs & 62 \\
\hline Economic & Economic benefit for the region & $\begin{array}{l}\text { Net income from the project/Income generated } \\
\text { by the region, excl. the project }\end{array}$ & 50 \\
\hline Technological & Cost of technology & Cost of technology/All costs & 43 \\
\hline Social & Safety of infrastructure & $\begin{array}{l}\text { Whether the zone is fenced and secured by } \\
\text { cameras (yes-1; no-0); Whether the zone is } \\
\text { secured by cameras (yes-0.5; no-0); Whether } \\
\text { the zone is fenced (yes-0.5; no-0) }\end{array}$ & 40 \\
\hline Environmental & Dust reduction & Tons of dust/Net income & 32 \\
\hline
\end{tabular}

Table 2, above, shows that, out of the 18 criteria, the most significant criterion is the emission of $\mathrm{CO}_{2}$, immediately followed by the health and well-being of workers, whereas, according to the experts, the dust reduction criterion is the least significant.

As Table 3 shows, according to the coefficient of variation, the experts' opinions were most united regarding $\mathrm{CO}_{2}$ emissions, the health and well-being of workers, innovative technologies employed and technical risks throughout the project life-cycle and feasibility criteria. On the other hand, the opinions differed most on criteria such as safety of infrastructure, cost of technology, economic benefit of the region and the degree of intellectual property protection.

Table 3. Statistics of expert survey results $(n=9)$.

\begin{tabular}{|c|c|c|c|c|c|c|c|}
\hline Criterion & $\begin{array}{c}\text { Min } \\
\text { Evaluation }\end{array}$ & $\begin{array}{c}\text { Max } \\
\text { Evaluation }\end{array}$ & Mean & Median & Mode & $\begin{array}{l}\text { Standard } \\
\text { Deviation }\end{array}$ & $\begin{array}{l}\text { Coefficient of } \\
\text { Variation }\end{array}$ \\
\hline Emission of $\mathrm{CO}_{2}$ & 12 & 18 & 16.89 & 17 & 17 & 5.28 & 0.31 \\
\hline Health and well-being of workers & 10 & 18 & 16.78 & 18 & 18 & 4.10 & 0.24 \\
\hline Employment of innovative technologies & 5 & 17 & 14.67 & 16 & 16 & 5.94 & 0.40 \\
\hline Overall project quality & 4 & 17 & 12.44 & 13 & 13 & 8.92 & 0.72 \\
\hline Use of renewable energy & 3 & 15 & 12.22 & 14 & 14 & 10.74 & 0.88 \\
\hline Quality control & 1 & 16 & 11.44 & 12 & 12 & 10.94 & 0.96 \\
\hline Waste management & 6 & 15 & 10.89 & 10 & 15 & 10.06 & 0.92 \\
\hline $\begin{array}{l}\text { Technical risks throughout the project } \\
\text { life-cycle and feasibility }\end{array}$ & 8 & 15 & 10.67 & 11 & 11 & 4.12 & 0.39 \\
\hline $\begin{array}{l}\text { Degree of intellectual property protection } \\
\text { (patents, trademarks, copyrights) }\end{array}$ & 2 & 16 & 10.22 & 15 & 15 & 16.99 & 1.66 \\
\hline Improvement of the life quality & 5 & 12 & 7.89 & 8 & 5 & 6.88 & 0.87 \\
\hline Time of construction & 4 & 9 & 7.33 & 8 & 8 & 4.46 & 0.61 \\
\hline
\end{tabular}


Table 3. Cont.

\begin{tabular}{cccccccc}
\hline Criterion & $\begin{array}{c}\text { Min } \\
\text { Evaluation }\end{array}$ & $\begin{array}{c}\text { Max } \\
\text { Evaluation }\end{array}$ & Mean & Median & Mode & $\begin{array}{c}\text { Standard } \\
\text { Deviation }\end{array}$ & $\begin{array}{c}\text { Coefficient of } \\
\text { Variation }\end{array}$ \\
\hline Post-construction energy consumption & 1 & 14 & 7.22 & 6 & 6 & 11.87 & 1.64 \\
\hline Reduction of direct costs & 3 & 11 & 7.11 & 8 & 8 & 7.83 & 1.10 \\
\hline Reduction of non-direct costs & 4 & 10 & 6.89 & 7 & 5 & 6.32 & 0.92 \\
\hline Economic benefit for the region & 2 & 15 & 5.56 & 4 & 4 & 11.42 & 2.06 \\
\hline Cost of technology & 1 & 10 & 4.78 & 5 & 1 & 10.49 & 2.20 \\
\hline Safety of infrastructure & 1 & 13 & 4.44 & 2 & 2 & 12.09 & 2.72 \\
\hline Dust reduction & 1 & 7 & 3.56 & 3 & 3 & 5.13 & 1.44 \\
\hline
\end{tabular}

Taking into consideration the fact that the opinions of experts vary and are not united regarding some criteria, there is a need to evaluate the degree of compatibility and consistency of opinions. The consistency of opinions was calculated using Kendall's concordance correlation coefficient (Formula (2)). After computing calculations, the value of coefficient was 0.58 , which shows that the agreement of the experts' opinions is strong. Moreover, the reliability of opinions was also calculated using Pearson's correlation coefficient (Formula (3)). The results indicate that the value of $\chi^{2}$ is higher than $\chi_{k r}^{2}(88.953>37.1565)$ at a significance level of $\alpha=0.05$. Therefore, these coefficients confirm that opinions of experts are consistent and reliable and, thus, can be used for further research.

With the answers from experts, the weight for each criterion could be determined, and each criterion should be divided into maximizing (positively affect sustainability) or minimizing (negatively affect sustainability) criteria based on its impact on sustainability.

According to Table 4, the technological dimension is the most important for the experts. This supports the fact stated in the literature analysis that technology currently plays a huge role as it facilitates adaptation to changing conditions and is fostered as a company's competitive advantage; therefore, it is crucial to include technology as a fourth sustainability dimension. The technological dimension is followed by the environmental dimension in order of significance. As regards individual criteria, $\mathrm{CO}_{2}$ emissions, the safety and well-being of workers, innovative technologies employed, overall project quality and use of renewable energy are among the most important factors for the experts. On the other hand, based on the expert opinions, the least significant criteria are dust reduction, safety of infrastructure, cost of technology, economic benefit of the region and reduction in non-direct costs.

Table 4. Weights and types of sustainability criteria.

\begin{tabular}{|c|c|c|c|c|}
\hline Dimension and Criterion & Code & Weight Coefficient in a Group & Total Weight Coefficient & Type \\
\hline Environmental & & 0.297 & & \\
\hline Emission of $\mathrm{CO}_{2}$ & $\mathrm{C} 1$ & 0.333 & 0.099 & Min \\
\hline Use of renewable energy & $\mathrm{C} 5$ & 0.241 & 0.071 & Max \\
\hline Waste management & $\mathrm{C} 7$ & 0.214 & 0.064 & Max \\
\hline Post construction energy consumption & C12 & 0.142 & 0.042 & Min \\
\hline Dust reduction & $\mathrm{C} 18$ & 0.070 & 0.021 & Min \\
\hline Social & & 0.170 & & \\
\hline Safety and well-being of workers & $\mathrm{C} 2$ & 0.576 & 0.098 & Max \\
\hline Improvement of the life quality & C10 & 0.271 & 0.046 & Max \\
\hline Safety of infrastructure & C17 & 0.153 & 0.026 & Max \\
\hline Economic & & 0.224 & & \\
\hline Quality control & C6 & 0.299 & 0.067 & Max \\
\hline Time of construction & C11 & 0.191 & 0.043 & Min \\
\hline Reduction of direct costs & C13 & 0.186 & 0.042 & Min \\
\hline Reduction of non-direct costs & C14 & 0.180 & 0.040 & Min \\
\hline Economic benefit for the region & $\mathrm{C} 15$ & 0.145 & 0.032 & $\operatorname{Max}$ \\
\hline
\end{tabular}


Table 4. Cont.

\begin{tabular}{|c|c|c|c|c|}
\hline Dimension and Criterion & Code & Weight Coefficient in a Group & Total Weight Coefficient & Type \\
\hline Technological & & 0.309 & & \\
\hline Employment of innovative technologies & $\mathrm{C} 3$ & 0.278 & 0.086 & Max \\
\hline Overall project quality & $\mathrm{C} 4$ & 0.236 & 0.073 & Max \\
\hline $\begin{array}{l}\text { Technical risks throughout the project } \\
\text { life-cycle and feasibility }\end{array}$ & $\mathrm{C} 8$ & 0.202 & 0.062 & Min \\
\hline $\begin{array}{l}\text { Degree of intellectual property protection } \\
\text { (patents, trademarks, copyrights) }\end{array}$ & C9 & 0.194 & 0.060 & Max \\
\hline Cost of technology & C16 & 0.091 & 0.028 & $\operatorname{Max}$ \\
\hline
\end{tabular}

Furthermore, the indication of the criterion type leads to criterion normalization, which is based on the highest maximizing and lowest minimizing values out of three analyzed alternatives (pessimistic, realistic and optimistic). For the SAW method, normalization is calculated by applying Formulas (4) and (5) based on the negative (min) or positive (max) impact on sustainability.

After normalization of variables, the next step is to compile an index by applying the SAW method. As mentioned above, the SAW method includes the summarization of weights; therefore, a sustainability index was calculated as follows:

$$
\begin{gathered}
\text { RESI }=0.099 C 1+0.098 C 2+0.086 C 3+0.073 C 4+0.071 C 5+0.067 C 6+0.064 C 7 \\
+0.062 C 8+0.060 C 9+0.046 C 10+0.043 C 11+0.042 C 12+0.042 C 13+0.040 C 14 \\
+0.032 C 15+0.028 C 16+0.026 C 17+0.021 C 18
\end{gathered}
$$

where RESI is a real estate sustainability index.

The value of the index is in the range between 0 and 1 , where the closer the value is to 1 , the higher the level of sustainability of a real estate project is.

\section{Conclusions}

The literature review showed that sustainability and sustainable development are currently gaining wide acknowledgment and becoming a relevant topic in the world. A special aspect that has to be considered and embedded in the notion of sustainability is the technological dimension.

The literature analysis also revealed that in order to reduce energy consumption in the real estate sector, there is a need for employing new technologies to boost energy efficiency. Therefore, the original concept of sustainability should be supplemented by an additional technological dimension, as it is the main tool for transitioning to a sustainable future. Ultimately, four-dimensional sustainability consideration within a real estate investment project portfolio is understood as a predominant challenge of present generations to create buildings and projects that will ensure a positive impact on the environment.

A real estate sustainability index (RESI) was constructed during the study by combining 18 criteria from four sustainability dimensions ( 5 environmental, 3 social, 5 economic and 5 technological), which were selected on the basis of the opinions and professional experience of nine experts. As indicated by the coefficient of variation, the expert opinions were mostly unanimous with regard to $\mathrm{CO}_{2}$ emission, health and well-being of workers and innovative technologies employed, whereas their opinions mostly differed on criteria such as safety of infrastructure, cost of technology and economic benefit of the region. In addition, the results of the study show that the technological dimension is the most significant for the experts. It therefore supports the fact that the concept of sustainability should be understood and expanded by an additional technological dimension. The technological inclusion is particularly important today as it allows for developing new technologies, which, in turn, are able to reduce the impact on climate change, replace natural gas by renewable energy sources, enhancing resource efficiency, bringing a competitive advantage in the market and improving living standards. 
The proposed real estate sustainability index could be used individually by decisionmakers or managers to assess the sustainability of a real estate project, compare alternatives and evaluate the level of value proposition against competitors as the concept of sustainability is expanded by the fourth-technological—dimension, which corresponds to adaptability to fast-changing business conditions. Therefore, embedding the technological dimension in the concept of sustainability corresponds to a novel theoretical approach to the assessment of project sustainability.

Author Contributions: Conceptualization, N.D., A.P. and M.T.; methodology, N.D.; software, N.D. and A.P.; validation, N.D., A.P. and M.T.; formal analysis, A.P.; investigation, N.D. and A.P.; resources, N.D., A.P. and M.T.; data curation, A.P.; writing-original draft preparation, N.D. and A.P.; writingreview and editing, N.D., A.P. and M.T. All authors have read and agreed to the published version of the manuscript.

Funding: This research received no external funding.

Institutional Review Board Statement: Not applicable.

Informed Consent Statement: Not applicable.

Data Availability Statement: Not applicable.

Acknowledgments: We would like to thank the Editor and the anonymous reviewers for the valuable comments and very useful suggestions. We would also like to thank Kristina Šatkuviene for the English language editing.

Conflicts of Interest: The authors declare no conflict of interest.

\section{References}

1. Banihashemi, S.; Hosseini, M.R.; Golizadeh, H.; Sankaran, S. Critical success factors (CSFs) for integration of sustainability into construction project management practices in developing countries. Int. J. Proj. Manag. 2017, 35, 1103-1119. [CrossRef]

2. Toan, N.Q.; Tam, N.V.; Hai, D.T.; Quy, N.L.D. Critical factors affecting labor productivity within construction project implementation: A project manager's perspective. Entrep. Sustain. Issues 2020, 8, 751-763. [CrossRef]

3. European Commission. Energy Performance of Buildings. 2019. Available online: https://ec.europa.eu/energy/en/topics/ energy-efficiency / energy-performance-of-buildings / overview (accessed on 22 September 2020).

4. Elkington, J. Cannibals with Forks: The Triple Bottom Line of 21st Century Business; Capstone Publishing: Oxford, UK, 1997.

5. Rajnoha, R.; Lesníková, P. Strategic Performance Management System and Corporate Sustainability Concept-Specific Parametres in Slovak Enterprises. J. Compet. 2016, 8, 107-124. [CrossRef]

6. Vogt, M.; Weber, C. Current challenges to the concept of sustainability. Glob. Sustain. 2019, 2. [CrossRef]

7. Purvis, B.; Mao, Y.; Robinson, D. Three pillars of sustainability: In search of conceptual origins. Sustain. Sci. 2019, 14, 681-695. [CrossRef]

8. Venturini, O.J.; Júnior, J.C.F.; Palacio, J.C.E.; Batlle, E.A.O.; Carvalho, M.; Lora, E.E.S. Indicators for sustainability assessment of biofuels: Economic, environmental, social, and technological dimensions. In Biofuels for a More Sustainable Future; Elsevier: Amsterdam, The Netherlands, 2020; pp. 73-113. [CrossRef]

9. Alcívar, I.L.; Santa Cruz, F.G.; Mero, N.M.; Hidalgo-Fernández, A. Study of Corporate Sustainability Dimensions in the Cooperatives of Ecuador. Sustainability 2020, 12, 462. [CrossRef]

10. Clune, W.H.; Zehnder, A.J. The evolution of sustainability models, from descriptive, to strategic, to the three pillars framework for applied solutions. Sustain. Sci. 2020, 1-6. [CrossRef]

11. Tian, N.; Tang, S.; Che, A.; Wu, P. Measuring regional transport sustainability using super-efficiency SBM-DEA with weighting preference. J. Clean. Prod. 2020, 242, 118474. [CrossRef]

12. $\mathrm{Wu}, \mathrm{J} . ; \mathrm{Wu}, \mathrm{T}$. Sustainability Indicators and Indices: An Overview. In Handbook of Sustainability Management. Available online: https:/ / doi.org/10.1142/9789814354820_0004 (accessed on 8 October 2020).

13. Dobrovolskienè, N.; Tamošiūnienè, R. An index to measure sustainability of a business project in the construction industry: Lithuanian case. Sustainability 2016, 8, 14. [CrossRef]

14. Sarma, U.; Karnitis, G.; Zuters, J.; Karnitis, E. District heating networks: Enhancement of the efficiency. Insights Reg. Dev. 2019, 1, 200-213. [CrossRef]

15. El Iysaouy, L.; El Idrissi, N.E.; Tvaronavičienė, M.; Lahbabi, M.; Oumnad, A. Towards energy efficiency: Case of Morocco. Insights Reg. Dev. 2019, 1, 259-271. [CrossRef]

16. Nasr, A.K.; Kashan, M.K.; Maleki, A.; Jafari, N.; Hashemi, H. Assessment of Barriers to Renewable Energy Development Using Stakeholders Approach. Entrep. Sustain. Issues 2020, 7, 2526-2541. [CrossRef] 
17. Igaliyeva, L.; Niyazbekova, S.; Serikova, M.; Kenzhegaliyeva, Z.; Mussirov, G.; Zueva, A.; Tyurina, Y.; Maisigova, L. Towards environmental security via energy efficiency: A case study. Entrep. Sustain. Issues 2020, 7, 3488-3499. [CrossRef]

18. Dobrovolskienè, N. Finansiniu ištekliu paskirstymas projektu portfelyje atsižvelgiant i darnumo aspektus. Ph.D. Thesis, Vilnius Gediminas Technical University (VGTU), Vilnius, Lithuania, 2016. (In Lithuanian)

19. Danish, M.S.S.; Senjyu, T.S. Green Building Efficiency and Sustainability Indicators. In Green Building Management and Smart Automation; IGI Global: Hershey, PA, USA, 2020; pp. 128-145. [CrossRef]

20. Fatimah, Y.A.; Govindan, K.; Murniningsih, R.; Setiawan, A. Industry 4.0 based sustainable circular economy approach for smart waste management system to achieve sustainable development goals: A case study of Indonesia. J. Clean. Prod. 2020, $269,122263$. [CrossRef]

21. García-Pérez, I.; Fernández-Izquierdo, M.Á.; Muñoz-Torres, M.J. Microfinance institutions fostering sustainable development by region. Sustainability 2020, 12, 2682. [CrossRef]

22. Dušková, M. Key enabling technologies and measuring of the company performance in relation to sustainable development: Evaluation model design. Int. J. Innov. Sustain. Dev. 2021, 15, 1-34. [CrossRef]

23. United Nations. Paris Agreement. 2015. Available online: https://ec.europa.eu/clima/policies/international/negotiations/ paris_en (accessed on 27 January 2021).

24. Bivainis, J. Vadyba Studentams: Mokomoji Knyga; Vilniaus Gedimino Technikos Universitetas: Vilnius, Lithuania, 2011; Available online: https:/ / dx.doi.org/10.3846/1229-S (accessed on 30 November 2020).

25. Skibniewski, M.J.; Zavadskas, E.K. Technology development in construction: A continuum from distant past into the future. $J$. Civ. Eng. Manag. 2013, 19, 136-147. [CrossRef]

26. Kildienè, S. Tvarios Statybos Technologiju Pletros Daugiapakopis Vertinimas. Ph.D. Thesis, Vilnius Gediminas Technical University (VGTU), Vilnius, Lithuania, 2014. (In Lithuanian)

27. Nowotny, J.; Dodson, J.; Fiechter, S.; Gür, T.M.; Kennedy, B.; Macyk, W.; Rahman, K.A. Towards global sustainability: Education on environmentally clean energy technologies. Renew. Sustain. Energy Rev. 2018, 81, 2541-2551. [CrossRef]

28. Bulbul, S.; Ertugrul, G.; Arli, F. Investigation of usage potentials of global energy systems. Int. Adv. Res. Eng. J. 2018,2 , 58-67.

29. Rogalev, A.; Komarov, I.; Kindra, V.; Zlyvk, O. Entrepreneurial assessment of sustainable development technologies for power energy sector. Enterp. Sustain. Issues 2018, 6, 429-445. [CrossRef]

30. Tyo, A.; Jazykbayeva, B.; Ten, T.; Kogay, G.; Spanova, B. Development tendencies of heat and energy resources: Evidence of Kazakhstan. Entrep. Sustain. Issues 2019, 7, 1514-1524. [CrossRef]

31. Dudin, M.N.; Frolova, E.E.; Protopopova, O.V.; Mamedov, A.A.; Odintsov, S.V. Study of innovative technologies in the energy industry: Nontraditional and renewable energy sources. Entrep. Sustain. Issues 2019, 6, 1704-1713. [CrossRef]

32. Orhan, M.F.; Kahraman, H.; Babu, B.S. Approaches for integrated hydrogen production based on nuclear and renewable energy sources: Energy and exergy assessments of nuclear and solar energy sources in the United Arab Emirates. Int. J. Hydrog. Energy 2017, 42, 2601-2616. [CrossRef]

33. Chehabeddine, M.; Tvaronavičienè, M. Securing regional development. Insights Reg. Dev. 2020, 2, 430-442. [CrossRef]

34. Mazzoni, F. Circular economy and eco-innovation in Italian industrial clusters. Best practices from Prato textile cluster. Insights Reg. Dev. 2020, 2, 661-676. [CrossRef]

35. Qiu, L.; Jie, X.; Wang, Y.; Zhao, M. Green product innovation, green dynamic capability, and competitive advantage: Evidence from Chinese manufacturing enterprises. Corp. Soc. Responsib. Environ. Manag. 2020, 27, 146-165. [CrossRef]

36. Marcelino-Sádaba, S.; González-Jaen, L.F.; Pérez-Ezcurdia, A. Using project management as a way to sustainability. From a comprehensive review to a framework definition. J. Clean. Prod. 2015, 99, 1-16. [CrossRef]

37. Dobrovolskienè, N.; Tamošiūnienè, R.; Banaitis, A.; Ferreira, F.A.; Banaitienè, N.; Taujanskaitè, K.; Meidutė-Kavaliauskienè, I. Developing a composite sustainability index for real estate projects using multiple criteria decision making. Oper. Res. 2019, 19, 617-635. [CrossRef]

38. Durdyev, S.; Zavadskas, E.K.; Thurnell, D.; Banaitis, A.; Ihtiyar, A. Sustainable construction industry in Cambodia: Awareness, drivers and barriers. Sustainability 2018, 10, 392. [CrossRef]

39. Si, J.; Marjanovic-Halburd, L.; Nasiri, F.; Bell, S. Assessment of building-integrated green technologies: A review and case study on applications of Multi-Criteria Decision Making (MCDM) method. Sustain. Cities Soc. 2016, 27, 106-115. [CrossRef]

40. Amending Directive on Energy Performance of Buildings. 2018. Available online: https://eur-lex.europa.eu/legal-content/EN/ TXT / ?uri=uriserv\%3AOJ.L_.2018.156.01.0075.01.ENG (accessed on 27 December 2020).

41. Eurostat. Europe 2020-Overview. 2019. Available online: https:/ / ec.europa.eu/eurostat/web/europe-2020-indicators (accessed on 27 December 2020).

42. Ramboll. Sustainable Buildings Content Sustainable Buildings Make. 2019. Available online: https://ramboll.com/- / media/files/ rgr/documents/markets/buildings/s/sustainable-buildings-market-study_2019_web.pdf?la=en (accessed on 21 January 2021).

43. Lazauskas, M. Statybos Projektu Darnos Vertinimo Kompleksinis Modelis. Ph.D. Thesis, Vilnius Gediminas Technical University (VGTU), Vilnius, Lithuania, 2015. (In Lithuanian)

44. Szery, K.; Sunindijo, R.Y. Occupant Satisfaction in Sustainable and Conventional Higher Education Buildings. In Eurasian Business Perspectives; Springer: Cham, Switzerland, 2019; pp. 95-111.

45. Mahmoud, S.; Zayed, T.; Fahmy, M. Development of sustainability assessment tool for existing buildings. Sustain. Cities Soc. 2019, 44, 99-119. [CrossRef] 
46. Li, Y.; Chen, X.; Wang, X.; Xu, Y.; Chen, P.H. A review of studies on green building assessment methods by comparative analysis. Energy Build. 2017, 146, 152-159. [CrossRef]

47. Hamedani, A.Z.; Huber, F. A comparative study of DGNB, LEED and BREEAM certificate systems in urban sustainability The Sustainable City VII, Vol. 1 121. Trans. Ecol. Environ. 2012, 155, 121-132.

48. Kaklauskas, A.; Kelpsiene, L.; Zavadskas, E.K.; Bardauskiene, D.; Kaklauskas, G.; Urbonas, M.; Sorakas, V. Crisis management in construction and real estate: Conceptual modeling at the micro-, meso-and macro-levels. Land Use Policy 2011, $28,280-293$. [CrossRef]

49. Morano, P.; Guarini, M.R.; Tajani, F.; Anelli, D. Sustainable Redevelopment: The Cost-Revenue Analysis to Support the Urban Planning Decisions. In International Conference on Computational Science and Its Applications; Springer: Cham, Switzerland, 2020; pp. 968-980.

50. Bottero, M.; Ferretti, V. Integrating the analytic network process (ANP) and the driving force-pressure-state-impact-responses (DPSIR) model for the sustainability assessment of territorial transformations. Manag. Environ. Qual. Int. J. 2010. [CrossRef]

51. Vučićević, B.; Jovanović, M.; Afgan, N.; Turanjanin, V. Assessing the sustainability of the energy use of residential buildings in Belgrade through multi-criteria analysis. Energy Build. 2014, 69, 51-61. [CrossRef]

52. Siew, R.Y.; Balatbat, M.C.; Carmichael, D.G. A proposed framework for assessing the sustainability of infrastructure. Int. J. Constr. Manag. 2016, 16, 1-18. [CrossRef]

53. Dahl, A.L. Achievements and gaps in indicators for sustainability. Ecol. Indic. 2012, 17, 14-19. [CrossRef]

54. Pintér, L.; Hardi, P.; Martinuzzi, A.; Hall, J. Bellagio STAMP: Principles for sustainability assessment and measurement. Ecol. Indic. 2012, 17, 20-28. [CrossRef]

55. Singh, R.K.; Murty, H.R.; Gupta, S.K.; Dikshit, A.K. An overview of sustainability assessment methodologies. Ecol. Indic. 2012, 15, 281-299. [CrossRef]

56. Waas, T.; Hugé, J.; Block, T.; Wright, T.; Benitez-Capistros, F.; Verbruggen, A. Sustainability assessment and indicators: Tools in a decision-making strategy for sustainable development. Sustainability 2014, 6, 5512-5534. [CrossRef]

57. O'Ryan, R.; Pereira, M. Participatory indicators of sustainability for the salmon industry: The case of Chile. Mar. Policy 2015, 51, 322-330. [CrossRef]

58. Mazzanti, M.; Mazzarano, M.; Pronti, A.; Quatrosi, M. Fiscal policies, public investments and wellbeing: Mapping the evolution of the EU. Insights Reg. Dev. 2020, 2, 725-749. [CrossRef]

59. Vasconcelos, V.V. Social justice and sustainable regional development: Reflections on discourse and practice in public policies and public budget. Insights Reg. Dev. 2021, 3, 10-28. [CrossRef]

60. Cinelli, M.; Coles, S.R.; Kirwan, K. Analysis of the potentials of multi criteria decision analysis methods to conduct sustainability assessment. Ecol. Indic. 2014, 46, 138-148. [CrossRef]

61. Mainali, B.; Silveira, S. Using a sustainability index to assess energy technologies for rural electrification. Renew. Sustain. Energy Rev. 2015, 41, 1351-1365. [CrossRef]

62. Oliveira, E.C.B.D.; Alencar, L.H.; Costa, A.P.C.S. A decision model for energy companies that sorts projects, classifies the project manager and recommends the final match between project and project manager. Production 2016, 26, 91-104. [CrossRef]

63. Ruiz, F.; Cabello, J.M.; Pérez-Gladish, B. Building Ease-of-Doing-Business synthetic indicators using a double reference point approach. Technol. Forecast. Soc. Chang. 2018, 131, 130-140. [CrossRef]

64. Kaklauskas, A.; Zavadskas, E.K.; Radzeviciene, A.; Ubarte, I.; Podviezko, A.; Podvezko, V.; Kuzminske, A.; Banaitis, A.; Binkyte, A.; Bucinskas, V. Quality of city life multiple criteria analysis. Cities 2018, 72, 82-93. [CrossRef]

65. Bithas, K. A bioeconomic approach to sustainability with ecological thresholds as an operational indicator. Environ. Sustain. Indic. 2020, 6, 100027. [CrossRef]

66. Lütje, A.; Wohlgemuth, V. Tracking Sustainability Targets with Quantitative Indicator Systems for Performance Measurement of Industrial Symbiosis in Industrial Parks. Adm. Sci. 2020, 10, 3. [CrossRef]

67. Mohanty, S.; Swain, C.K.; Kumar, A.; Nayak, A.K. Nitrogen Footprint: A Useful Indicator of Agricultural Sustainability. In Nutrient Dynamics for Sustainable Crop Production; Springer: Singapore, 2020; pp. 135-156.

68. Reid, J.; Rout, M. Developing sustainability indicators-The need for radical transparency. Ecol. Indic. 2020, 110, 105941. [CrossRef]

69. Binder, C.R.; Hutter, M.; Pang, M.; Webb, R. System science and sustainability assessment. Sustain. Assess. Urban Syst. 2020, $30,30-64$.

70. Chen, C.; Yu, Y.; Osei-Kyei, R.; Chan, A.P.C.; Xu, J. Developing a project sustainability index for sustainable development in transnational public-private partnership projects. Sustain. Dev. 2019, 27, 1034-1048. [CrossRef]

71. Carvalho, A.C.V.D.; Granja, A.D.; Silva, V.G.D. Use of a card game tool to capture end users' preferences and add sustainability value to social housing projects. Ambiente Construído 2020, 20, 7-20. [CrossRef]

72. Zavadskas, E.K.; Turskis, Z. Multiple criteria decision making (MCDM) methods in economics: An overview. Technol. Econ. Dev. Econ. 2011, 17, 397-427. [CrossRef]

73. Kasim, M.M. Multi-criteria decision making methods for determining computer preference index. J. Inf. Commun. Technol. 2020, 10, 137-148.

74. Paredes-Gazquez, J.D.; Rodriguez-Fernandez, J.M.; de la Cuesta-Gonzalez, M. Measuring corporate social responsibility using composite indices: Mission impossible? The case of the electricity utility industry. Rev. Contab. 2016, 19, 142-153. [CrossRef]

75. Marttunen, M.; Belton, V.; Lienert, J. Are objectives hierarchy related biases observed in practice? A meta-analysis of environmental and energy applications of multi-criteria decision analysis. Eur. J. Oper. Res. 2018, 265, 178-194. [CrossRef] 
76. Ferretti, V. From stakeholders analysis to cognitive mapping and Multi-Attribute Value Theory: An integrated approach for policy support. Eur. J. Oper. Res. 2016, 253, 524-541. [CrossRef]

77. Ferreira, F.A.; Spahr, R.W.; Sunderman, M.A. Using multiple criteria decision analysis (MCDA) to assist in estimating residential housing values. Int. J. Strateg. Prop. Manag. 2016, 20, 354-370. [CrossRef]

78. Marinakis, V.; Doukas, H.; Xidonas, P.; Zopounidis, C. Multicriteria decision support in local energy planning: An evaluation of alternative scenarios for the sustainable energy action plan. Omega 2017, 69, 1-16. [CrossRef]

79. Galariotis, E.; Guyot, A.; Doumpos, M.; Zopounidis, C. A novel multi-attribute benchmarking approach for assessing the financial performance of local governments: Empirical evidence from France. Eur. J. Oper. Res. 2016, 248, 301-317. [CrossRef]

80. Xidonas, P.; Mavrotas, G.; Hassapis, C.; Zopounidis, C. Robust multiobjective portfolio optimization: A minimax regret approach. Eur. J. Oper. Res. 2017, 262, 299-305. [CrossRef]

81. Korotkov, V.; Wu, D. Evaluating the quality of solutions in project portfolio selection. Omega 2020, 91, 102029. [CrossRef]

82. Allaoui, H.; Guo, Y.; Choudhary, A.; Bloemhof, J. Sustainable agro-food supply chain design using two-stage hybrid multiobjective decision-making approach. Comput. Oper. Res. 2018, 89, 369-384. [CrossRef]

83. Dong, Y.; Liu, Y.; Liang, H.; Chiclana, F.; Herrera-Viedma, E. Strategic weight manipulation in multiple attribute decision making. Omega (UK) 2018, 75, 1339-1351. [CrossRef]

84. Podvezko, V. The Comparative Analysis of MCDA Methods SAW and COPRAS. Eng. Econ. 2011, 22, 134-146. [CrossRef]

85. Martín-Gamboa, M.; Iribarren, D.; García-Gusano, D.; Dufour, J. A review of life-cycle approaches coupled with data envelopment analysis within multi-criteria decision analysis for sustainability assessment of energy systems. J. Clean. Prod. 2017. [CrossRef]

86. Srisawat, C. Comparison of MCDM methods for intercrop selection in rubber plantations. J. Inf. Commun. Technol. 2020, 15, 165-182. [CrossRef]

87. Ibrahim, A.; Surya, R.A. The Implementation of Simple Additive Weighting (SAW) Method in Decision Support System for the Best School Selection in Jambi. J. Phys. Conf. Ser. 2019, 1338, 012054. [CrossRef]

88. Kumar, K.; Garg, H. TOPSIS method based on the connection number of set pair analysis under interval-valued intuitionistic fuzzy set environment. Comput. Appl. Math. 2018, 37, 1319-1329. [CrossRef]

89. Lakshmi, T.M.; Venkatesan, V.P.; Martin, A. An Identification of Better Engineering College with Conflicting Criteria using Adaptive TOPSIS. Int. J. Mod. Educ. Comput. Sci. 2016, 8, 19-31. [CrossRef]

90. Zimmer, K.; Fröhling, M.; Schultmann, F. Sustainable supplier management-a review of models supporting sustainable supplier selection, monitoring and development. Int. J. Prod. Res. 2016, 54, 1412-1442. [CrossRef]

91. Roszkowska, E. Multi-criteria decision making models by applying the TOPSIS method to crisp and interval data. Mult. Criteria Decis. Mak. Univ. Econ. Katow. 2011, 6, 200-230.

92. Khosravi, K.; Shahabi, H.; Pham, B.T.; Adamowski, J.; Shirzadi, A.; Pradhan, B.; Dou, J.; Ly, H.B.; Gróf, G.; Ho, H.L.; et al. A comparative assessment of flood susceptibility modeling using Multi-Criteria Decision-Making Analysis and Machine Learning Methods. J. Hydrol. 2019, 573, 311-323. [CrossRef]

93. Podvezko, V.; Podviezko, A. Kriteriju reikšmingumo nustatymo metodai. Liet. Mat. Rink. 2014. [CrossRef]

94. Fernández-Sánchez, G.; Rodríguez-López, F. A methodology to identify sustainability indicators in construction project management-Application to infrastructure projects in Spain. Ecol. Indic. 2010, 10, 1193-1201. [CrossRef]

95. Saaty, T.L. Applications of analytical hierarchies. Math. Comput. Simul. 1979, 21, 1-20. [CrossRef]

96. Podvezko, V. Sudètingų Dydžių Kompleksinis Vertinimas; Verslas Teorija ir praktika: Vilnius, Lithuania, 2008 ; pp. 160-168.

97. Ginevičius, R.; Podvezko, V. Daugiakriterinio vertinimo bųdu suderinamumas. Verslas Teor. Prakt. 2008, 9, 73-80. (In Lithuanian) [CrossRef]

98. Zhou, L.; Tokos, H.; Krajnc, D.; Yang, Y. Sustainability performance evaluation in industry by composite sustainability index. Clean Technol. Environ. Policy 2012, 14, 789-803. [CrossRef]

99. Podvezko, V. Comprehensive evaluation of complex quantities. Bus Theory Pract. 2008, 9, 160-168. [CrossRef]

100. Chen, Y.; Okudan, G.E.; Riley, D.R. Sustainable performance criteria for construction method selection in concrete buildings. Autom. Constr. 2010, 19, 235-244. [CrossRef]

101. Ding, G.K.C. Sustainable construction-The role of environmental assessment tools. J. Environ. Manag. 2008, 86, 451-464. [CrossRef] [PubMed]

102. Presley, A.; Meade, L. Benchmarking for sustainability: An application to the sustainable construction industry. Benchmark. Int. J. 2010, 17, 435-451. [CrossRef]

103. Siew, R.Y.J. A review of sustainability reporting tools (SRT's) for Communities. Int. J. Sustain. Constr. Eng. Technol. 2014, 5, $2180-3242$.

104. Siew, R.Y.J.; Balatbat, M.C.A.; Carmichael, D.G. A review of buildings/infrastructure Sustainability Reporting Tools (SRT's). Smart Sustain. Built Environ. 2013, 2, 106-139.

105. Akhanova, G.; Nadeem, A.; Kim, J.R.; Azhar, S. A multi-criteria decision-making framework for building sustainability assessment in Kazakhstan. Sustain. Cities Soc. 2020, 52, 101842. [CrossRef]

106. Sánchez Cordero, A.; Gómez Melgar, S.; Andújar Márquez, J.M. Green Building Rating Systems and the New Framework Level (s): A Critical Review of Sustainability Certification within Europe. Energies 2020, 13, 66. [CrossRef]

107. Kwatra, S.; Kumar, A.; Sharma, P. A critical review of studies related to construction and computation of Sustainable Development Indices. Ecol. Indic. 2020, 112, 106061. [CrossRef] 
108. Chan, J.H.; Chan, T.Y. Current Trends of Developing Energy Efficiency Projects in the Building Sector of China. In Sustainable Energy and Green Finance for a Low-carbon Economy; Springer: Cham, Switzerland, 2020; pp. 227-244.

109. Xu, X.; Wang, Y.; Tao, L. Comprehensive evaluation of sustainable development of regional construction industry in China. J. Clean Prod. 2019, 211, 1078-1087. [CrossRef] 